CZASOPISMO INŻYNIERII LĄDOWEJ, ŚRODOWISKA I ARCHITEKTURY JOURNAL OF CIVIL ENGINEERING, ENVIRONMENT AND ARCHITECTURE JCEEA, t. XXXIII, z. 63 (3/16), lipiec-wrzesień 2016, s. 85-93

Tomasz GACZOŁ ${ }^{1}$

\title{
PODCIŚNIENIOWY I NADCIŚNIENIOWY SYSTEM WENTYLACJI GRAWITACYJNEJ
}

\begin{abstract}
Wentylacja grawitacyjna, polega na wymianie powietrza, powstałej z powodu różnicy ciśnień, odbywająca się w sposób ciągły, poprzez przewody wentylacyjne. Jest to stary, sprawdzony i najczęściej stosowany sposób wentylowania pomieszczeń. Złe rozwiązania projektowe, powodują brak skutecznego jej działania. Najczęstszym popełnianym przez projektantów błędem jest zły dobór przekroju poprzecznego pola powierzchni wywiewnego kanału wentylacyjnego w stosunku do jego wysokości, a zatem do występującego w nim ciągu. Wielokrotnie pomijane są wymogi normowe dotyczące konieczności zapewnienia, odpowiedniej krotności wymiany powietrza lub strumienia przepływu powietrza mierzonego $\mathrm{w} \mathrm{m}^{3} / \mathrm{s}$. Na skutek tych zaniedbań dochodzi do zróżnicowanych efektów wentylacji pomieszczeń występujących na różnych kondygnacjach. Przedstawiony artykuł ma na celu omówienie i spopularyzowanie opracowanej przez autora metody, która umożliwia uzyskanie na każdej kondygnacji tych samych wyników poprawnego działania wymiany powietrza. Rodzaj systemu; podciśnieniowy lub nadciśnieniowy zależy jedynie od kondygnacji, na której został zastosowany. Przedstawione rozwiązanie jest bardzo prostym pomysłem na modernizację istniejących i projektowanie nowych budynków. Nie wymaga dużych nakładów finansowych i działa samoczynnie, ponieważ jest to system wentylacji grawitacyjnej bez żadnych elementów wspomagania. Poprawnie działająca wentylacja grawitacyjna odpowiada za zdrowie i dobre samopoczucie ludzi przebywających w budynku, a także za uzyskanie dobrych parametrów mikroklimatycznych np. wilgotność, temperatura czy prawidłowa, ujemna jonizacja powietrza. Odpowiedni stan techniczny przegród budowlanych i innych elementów obiektu, bez występujących zawilgoceń, zagrzybień to także efekt dobrze działającej wentylacji grawitacyjnej.
\end{abstract}

Słowa kluczowe: nadciśnienie, podciśnienie, nawiew, wywiew, krotność wymiany, strumień powietrza

\section{Wybór tematu}

Wzmożone prace budowlane w zakresie termomodernizacji obiektów budowlanych oraz ograniczenie napływu odpowiedniego strumienia powietrza do

\footnotetext{
${ }^{1}$ Tomasz Gaczoł, Politechnika Krakowska, Wydział Architektury, Instytut Projektowania Budowlanego, ul. Warszawska 24, 31-155 Kraków, tel. nr: 126282459, 500445876, e-mail: at.polgac@neostrada.pl
} 
pomieszczeń, sprawia coraz częściej spotykane problemy związane z nieprawidłowo działającą wentylacją grawitacyjną działającą okresowo oraz ze zmienną wydajnością. W Polsce istniejące budynki mieszkalne to w większości przypadków, obiekty powstałe w oparciu o system wentylacji grawitacyjnej. Według wymagań PN-83/B-03430, również nowe obiekty o wysokości do 9 kondygnacji mogą być wyposażone w system wentylacji grawitacyjnej. W obu przypadkach proponowane przeze mnie rozwiązanie może mieć szerokie zastosowanie w naszym kraju. Nie wymaga ono stosowania dużych nakładów finansowych oraz użycia skomplikowanych, drogich urządzeń wentylacyjnych. Wzorem wielu światowych znanych realizacji, które powstały w oparciu o wybrany system wentylacji naturalnej, może przynieść zadawalające efekty, przede wszystkim związane z ludzkim zdrowiem i dobrym stanem technicznym obiektów.

\section{Wentylacja grawitacyjna}

Wentylację grawitacyjną uzyskuje się poprzez połączenie z otoczeniem wewnętrznej kubatury pomieszczenia za pomocą kanału wentylacyjnego wyprowadzonego ponad poziom dachu. Płaszczyzna wyrównania ciśnienia znajduje się ponad pomieszczeniem, tak więc w całym jego wnętrzu panuje mniejsze ciśnienie od atmosferycznego. Taki sposób wentylowania nosi nazwę wentylacji grawitacyjnej wywiewnej [1],[2]. System działa bez zakłóceń pod warunkiem, że do wentylowanych pomieszczeń istnieje stały napływ powietrza zewnętrznego. Na skutek zamontowania nowej szczelnej stolarki okiennej i drzwiowej, modernizacji termicznej budynków dochodzi do uszczelnienia budynków oraz zakłócenia poprawnego działania systemu wentylacji grawitacyjnej. Może to doprowadzić do pojawienia się ciągu wstecznego w kanałach wentylacyjnych, a co za tym idzie do wielu przykrych konsekwencji z zagrożeniem zdrowia i życia ludzkiego włącznie [3]. Dbając o to, by do tego nie doszło należy zaprojektować urządzenia lub rozwiązania umożliwiające swobodny napływ powietrza do pomieszczeń. Jednym $\mathrm{z}$ takich rozwiązań projektowych jest czerpnia powietrza i nawiewny kanał wentylacji grawitacyjnej.

\section{Czerpnia powietrza}

Projektując system podciśnieniowej lub nadciśnieniowej wentylacji grawitacyjnej należy w pierwszej kolejności zapewnić prawidłowy dopływ powietrza do budynku. Do tego celu służyć będzie czerpnia powietrza, która może być usytuowana od strony północnej, wschodniej lub północno - wschodniej, np. w części podpiwniczenia lub przyziemia obiektu. Czerpnię należy zaprojektować w bezpośrednim sąsiedztwie pionowych kanałów wentylacji grawitacyjnej. Pomieszczenie na nią przeznaczone, powinno być ogrzewane (zalecana temperatura powietrza, w zakresie od $16^{\circ} \mathrm{C}$ do $18^{\circ} \mathrm{C}$, wilgotność względna od $40 \%$ do $60 \%$ ), okresowo czyszczone i posiadać wszystkie ściany i podłogę wykonane z materiałów zmy- 
walnych. Jego powierzchnia to nie mniej niż $2.0 \mathrm{~m}^{2}$, a wysokość przynajmniej $2.2 \mathrm{~m}$ (te wartości wynikają ze zwykłych potrzeb użytkowych). Kratka nawiewna czerpni, musi być zamontowana na wysokości minimum 100 centymetrów od powierzchni terenu i wyposażona $\mathrm{w}$ filtr, co zabezpieczy przed przedostaniem się do niej drobin kurzu, pyłu i innych zanieczyszczeń. Pole przekroju poprzecznego kanału wlotu powietrza do czerpni, musi być przynajmniej dwa razy większe od sumy pól powierzchni przekrojów poprzecznych kanałów nawiewnych dostarczających powietrze z czerpni do poszczególnych pomieszczeń użytkowych. Wynika to z oporów występujących podczas przepływu mas powietrza przez filtr oraz jego ruch, który w pomieszczeniach zamkniętych nie powinien przekraczać $0,5 \mathrm{~m} / \mathrm{s}$, a optymalna jego wartość to $0,15 \mathrm{~m} / \mathrm{s}$ (polskie normy określają prędkość przepływu powietrza $\mathrm{w}$ pomieszczeniach zamkniętych na poziomie $0,7 \mathrm{~m} / \mathrm{s}$ ) [4],[5]. Czerpnia może być również połączona $\mathrm{z}$ gruntowym zasobnikiem powietrza, umieszczonym pod ziemią, poniżej poziomu zamarzania gruntu. W zasobniku, powietrze służące do wentylacji wstępnie się ogrzewa, dzięki czemu uzyskuje się oszczędności wynikające ze znikomych strat ciepła na skutek wymiany powietrza w pomieszczeniach [6]. Szczegółowe przepisy dotyczące wymogów stawianych czerpni oraz wyrzutni powietrza, znajdują się w: Dzienniku Ustaw 2013 poz. 926: „Rozporządzenie Ministra Transportu, Budownictwa i Gospodarki Morskiej z dnia 5 lipca 2013 r. zmieniające rozporządzenie w sprawie warunków technicznych, jakim powinny odpowiadać budynki i ich usytuowanie" [7].

\section{Sposób działania}

W pierwszym przypadku rozważaniom zostanie poddane pomieszczenie, położone na niskiej kondygnacji budynku. Jest ono zazwyczaj wyposażone w długi, biegnący pionowo przez całą wysokość budynku, kanał wentylacji grawitacyjnej. W pomieszczeniu dochodzi do powstania podciśnienia, a zjawisko to ulega wzmożeniu w momencie kiedy napływ powietrza jest ograniczony. Dzieje się tak ponieważ powietrze wypełniające kubaturę pomieszczenia jest cały czas zasysane i odprowadzane na zewnątrz, poprzez wysoki kanał wentylacji grawitacyjnej wywiewnej. Zakładając, że tym samym przemurowanym kanałem (jeżeli schodzi do poziomu czerpni powietrza) lub nowo projektowanym, doprowadzimy z czerpni do wentylowanego pomieszczenia zewnętrzne masy powietrza, to dojdzie do wyrównania różnicy ciśnień. Napływ i odpływ, będzie się odbywał tym samym strumieniem powietrza bez względu na to, że w pomieszczeniu są szczelnie zamknięte okna, a budynek jest poddany termomodernizacji. Warunkiem koniecznym do spełnienia takiej wymiany, jest rozdzielenie od siebie kanałów: nawiewnego i wywiewnego. Jeżeli system będzie działał w oparciu o istniejący przewód wentylacji grawitacyjnej, to pomiędzy wlotem i wylotem kanału należy je rozdzielić (zamurować). Jeżeli jednak istniejący kanał wentylacji grawitacyjnej zaczyna się dopiero na poziomie wentylowanej kondygnacji, to należy do niej doprowadzić nowy kanał nawiewny (rys. 1, rys. 2). 


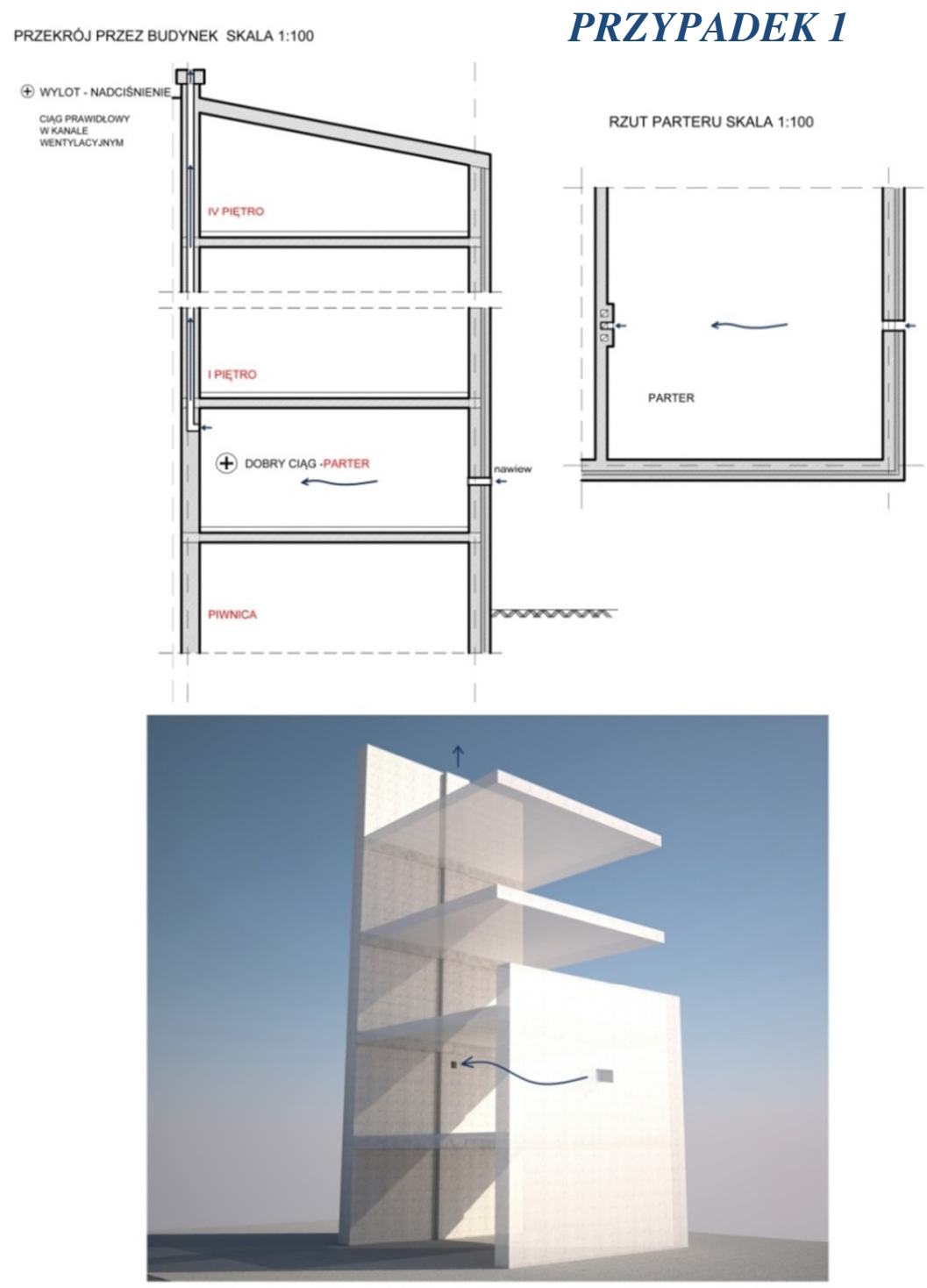

Rys. 1. Wentylacja grawitacyjna. Rozkład ciśnienia w budynku z kanałem wywiewnym. Różnica ciśnień - rysunek autora

Fig. 1. Gravitational ventilation. Pressure distribution in building with the exhaust duct. Pressure differential - figure of the author 


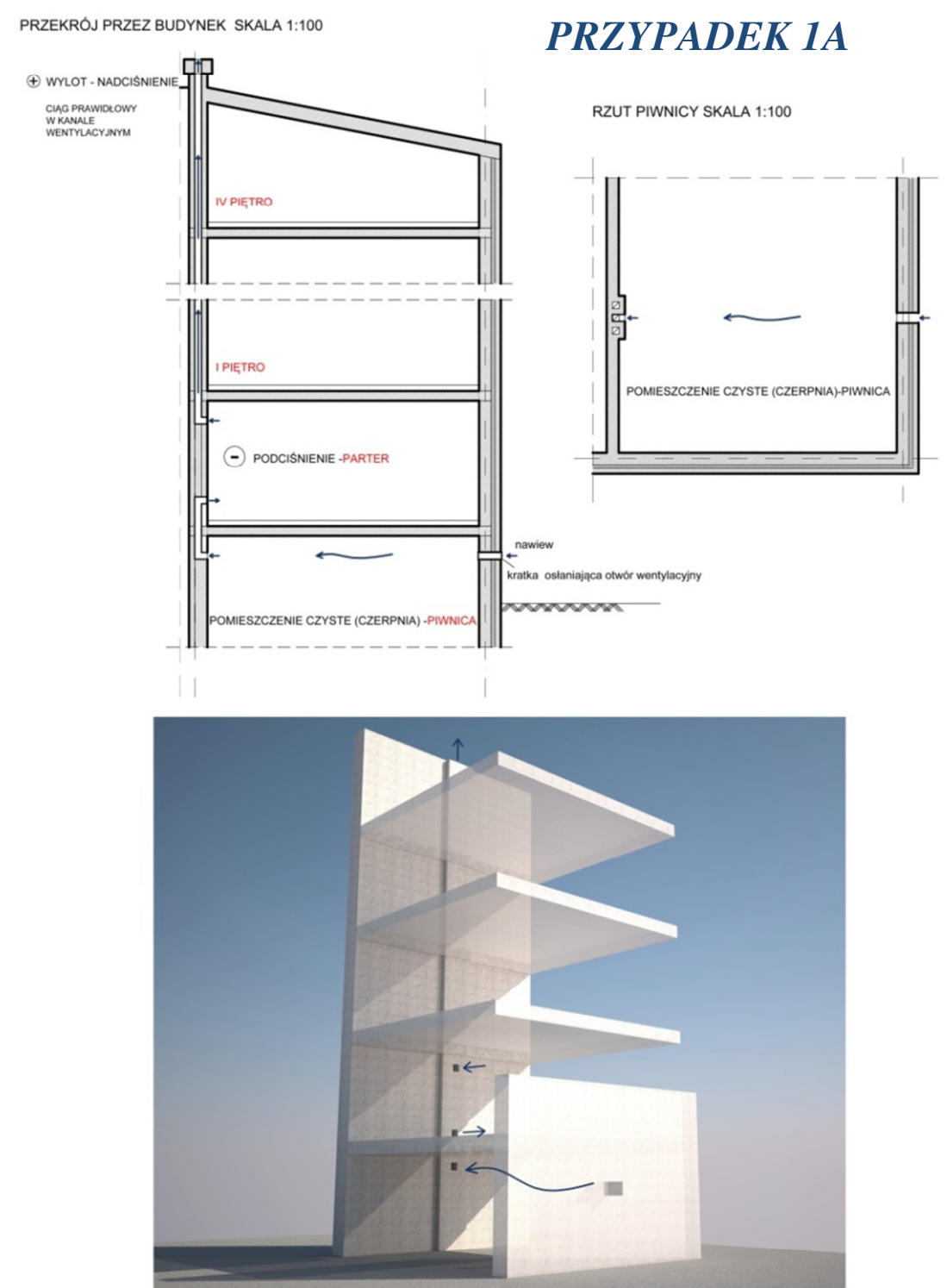

Rys. 2. Wentylacja grawitacyjna. Rozkład ciśnienia w budynku z kanałem nawiewnym i wywiewnym. Różnica ciśnień - rysunek autora

Fig. 2. Gravitational ventilation. Pressure distribution in building with the inhaust and exhaust duct. Pressure differential - figure of the author 

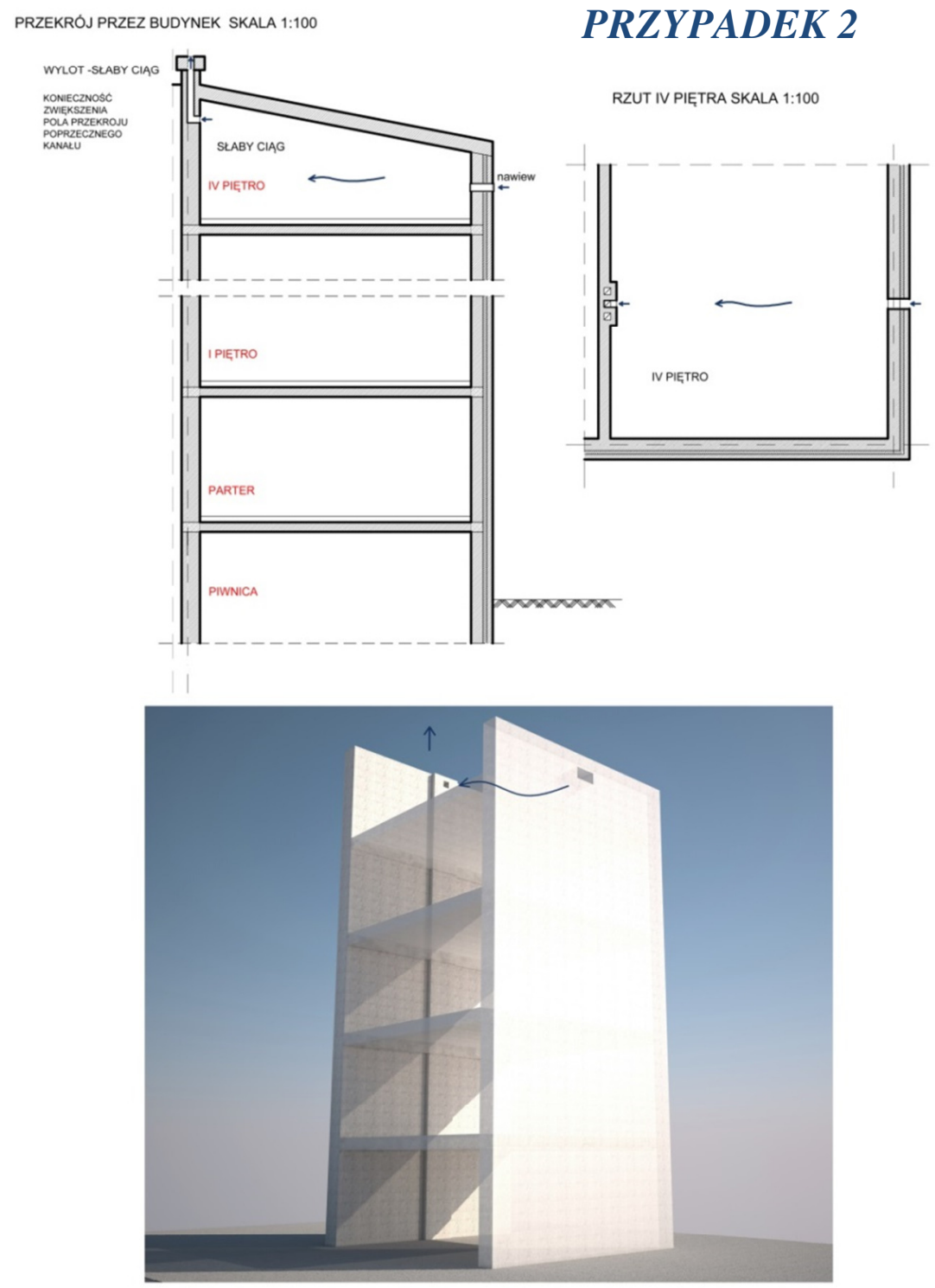

Rys. 3. Wentylacja grawitacyjna. Rozkład ciśnienia w budynku z kanałem wywiewnym. Różnica ciśnień - rysunek autora

Fig. 3. Gravitational ventilation. Pressure distribution in building with the exhaust duct. Pressure differential - figure of the author 


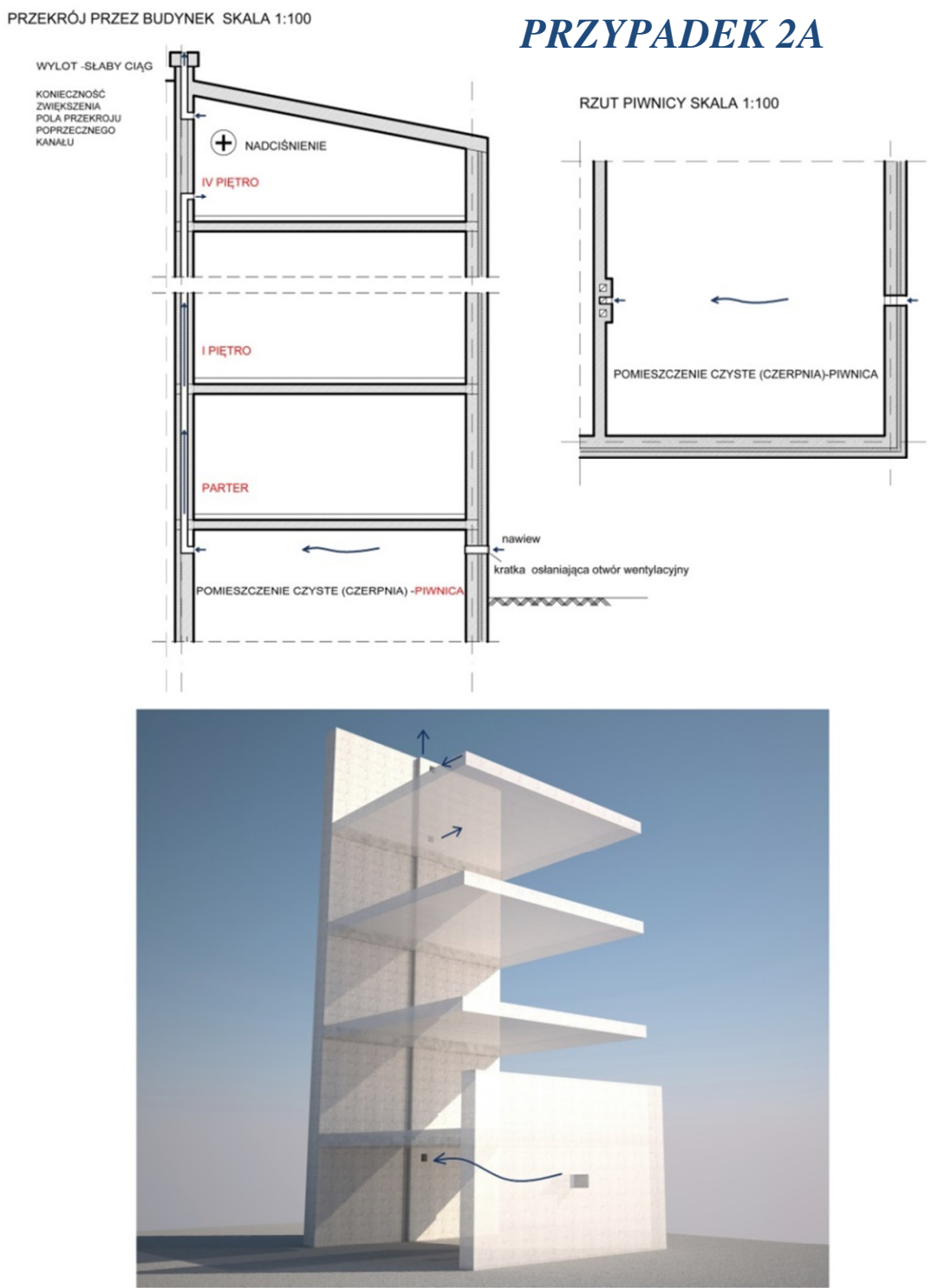

Rys. 4. Wentylacja grawitacyjna. Rozkład ciśnienia w budynku z kanałem nawiewnym i wywiewnym. Różnica ciśnień - rysunek autora

Fig. 4. Gravitational ventilation. Pressure distribution in building with the inhaust and exhaust duct. Pressure differential - figure of the author 
W drugim przypadku rozważaniom zostanie poddane pomieszczenie, na wysoko położonej kondygnacji budynku. Jest ono zazwyczaj wyposażone w krótki, biegnący pionowo, kanał wentylacji grawitacyjnej. W pomieszczeniu dochodzi do powstania podciśnienia, a zjawisko to ulega wzmożeniu w momencie kiedy napływ powietrza jest ograniczony. Dzieje się tak ponieważ powietrze wypełniające kubaturę pomieszczenia jest cały czas zasysane i powinno zostać odprowadzone na zewnątrz. Zakładając, że tym samym przemurowanym kanałem (jeżeli schodzi do poziomu czerpni powietrza) lub nowo projektowanym, doprowadzimy z czerpni do wentylowanego pomieszczenia zewnętrzne masy powietrza, to dojdzie do wzmożonego, grawitacyjnego napływu powietrza do pomieszczenia. Napływ i odpływ, będzie się odbywał tym samym strumieniem powietrza. W ten sposób pomieszczenia położone na różnych kondygnacjach są w równym stopniu wentylowane bez względu na różnicę wysokości kanału wywiewnego, zakładając przy tym ten sam wymiar jego przekroju poprzecznego (rys. 3, rys. 4).

\section{Wnioski}

Wentylacja grawitacyjna ma istotny wpływ na warunki higieniczne w pomieszczeniach budynków mieszkalnych. Odpowiednia ilość świeżego powietrza zapewnia człowiekowi dobre samopoczucie, a przede wszystkim decyduje o jego zdrowiu.

Głównym powodem podjęcia tematu jest:

- poprawa wydajności systemu wentylacji grawitacyjnej w nowych budynkach oraz w obiektach istniejących, poddanych termomodernizacji (docieplenie ścian zewnętrznych, montaż nowych szczelnych okien i drzwi),

- przestarzałe, normowe wytyczne projektowe (stare normy i przepisy) dotyczące wentylacji grawitacyjnej,

- zła jakość powietrza, znajdującego się w pomieszczeniach i chorobowe zagrożenia $\mathrm{z}$ tym związane,

- oszczędności energetyczne uzyskane zazwyczaj, poprzez ograniczenie przepływu powietrza przez budynek,

- dbałość o dobry stan techniczny elementów budowlanych i wyposażenia budynku (brak zawilgoceń i zagrzybień).

\section{Literatura:}

[1] Ferencowicz J.: „Wentylacja i klimatyzacja”. Warszawa, Arkady 1964. Wydanie 2, s.: 641.

[2] Polski Związek Inżynierów i Techników Budownictwa: "Poradnik inżyniera i technika budowlanego". Warszawa, Arkady 1968, tom 2 część III, s. 373 oraz 385.

[3] Kusionowicz T.: „Problemy projektowania budynków mieszkalnych, a zdrowie człowieka". Monografia, Kraków 2008. Politechnika Krakowska, seria architektura, s. $43,51,52$. 
[4] Rozporządzenie Ministra Infrastruktury „W sprawie warunków technicznych, jakim powinny odpowiadać budynki i ich usytuowanie". z dnia 12 kwietnia 2002 r. (Dz.U. $\mathrm{Nr} 75$, poz. 690) ze zmianami.

[5] PN-83/B-03430 (wraz ze zmianą A3:2000) „Wentylacja w budynkach mieszkalnych, zamieszkania zbiorowego i użyteczności publicznej. Wymagania".

[6] Gaczoł T. „Wentylacja naturalna. Systemy nawiewu - wybrane przykłady”. Kraków 2007. Czasopismo Techniczne Politechniki Krakowskiej. Architektura z. 4-A/2007, s. $63-70$.

[7] Dzienniku Ustaw 2013 poz. 926: „Rozporządzenie Ministra Transportu, Budownictwa i Gospodarki Morskiej z dnia 5 lipca 2013 r. zmieniające rozporządzenie w sprawie warunków technicznych, jakim powinny odpowiadać budynki i ich usytuowanie".

\section{VACUUM AND PRESURE RELIEF SYSTEM OF NATURAL VENTI- LATION}

\section{S u m m a r y}

This paper aims the discuss and popularizing described by the author method, which allows the same results for on each floors of proper air exchange operation. Type of system; vacuum or overpressure depends only on floor, at which was applied. The proposed solution is a very simple idea to modernize both the existing and new designed buildings. It does not require large financial outlays and it operates automatically, as this is the natural ventilation system without any support compounds. A properly functioning natural ventilation is responsible for the health and well-being of people living in the building, as well as gain good parameters of the microenvironment as humidity, temperature and proper, negative air ionization. Suitable condition of building partitions and other elements of the object, without appearing of moisture, molds is also the important effect of a well working natural gravity ventilation.

Keywords: natural ventilation, hypertension, hypotension, ventilation, exhaust, times of exchange, the air stream

DOI:10.7862/rb.2016.189

Przestano do redakcji: $30.06 .2016 r$.

Przyjęto do druku: 30.11.2016 r. 